\title{
Bilinçli Farkındalık Ölçeği Ergen Formu'nun Geçerlik ve Güvenirlik Çalışması
}

\author{
DOI: 10.26466/opus.683364
}

*

\section{Mehmet Emin Turan *}

* Dr. Öğr. Üyesi, Ağrı İbrahim Çeçen Üniversitesi, Eğitim Fakültesi, Eğitim Bilimleri Bölümü, Rehberlik Ve Psikolojik Danışmanlık Ana Bilim Dalı

\section{Öz}

E-Posta: meturan@agri.edu.tr

ORCID: 0000-0001-8092-9642

Bu araştırmanın amacı Bilinçli Farkındalık Ölçeği Ergen Formu'nu (BFÖ-EF) uyarlamak, geçerlik ve güvenirlik çalışmasını yapmaktır. Bu çalışma İstanbul'da yaşayan, 105'i kız, 116'sı erkek olmak üzere 221 katılımcı üzerinden yürütülmüştür. Ölçeğin yapı geçerliğini değerlendirmek için doğrulayıcı faktör analizi uygulanmıştır. Ölçeğin güvenirlik çalışması için, cronbach's alpha, iki yarı test güvenirliği ve madde toplam puan korelasyonları kullanılmıştır. Doğrulayıcı faktör analizi sonuçları, ki-kare değgerlerinin anlamlı ( $\chi 2=131.84, S D=77, p=.00010)$ ve uyum iyiliği değerlerinin kabul edilebilir (RMSEA $=.057, \mathrm{GFI}=.92, \mathrm{AGFI}=.89, \mathrm{CFI}=.93, \mathrm{IFI}=.93, \mathrm{NNFI}=.92, \mathrm{SRMR}=.060)$ düzeyde olduğunu göstermiştir. Analiz sonuçları ölçeğin Türkçe formunun faktör yapısının iyi uyum değerleri sağladı̆̆ı ve ölçeğin faktör yapısının orijinal ölçeğe paralel bir biçimde doğrulandığını göstermektedir. Güvenirlik değerleriaçısından incelendiğinde ölçeğin Türkçe formunun iç-tutarlılık güvenirlik katsayısının .78, iki yart test güvenirliğinin .76 olduğu ve düzeltilmiş madde toplam korelasyonların .26 ve .52 arasında sıralandığı görülmektedir. Analiz sonuçları Bilinçli Farkındalık Ölçeği Ergen Formu'nun Türkçe uyarlamasının geçerli ve güvenilir bir ölçme aracı olarak değerlendirilebileceğini göstermektedir.

Anahtar Kelimeler: Bilinçli farkındalık, ölçek uyarlama, güvenirlik, geçerlik, doğrulayıcı faktör analizi 


\title{
Validity and Reliability Study of Mindful Attention Awareness Scale Adolescent Form
}

\begin{abstract}
The aim of this study is to adapt the Mindful Attention Awareness Scale Adolescent Form (MAAS-A) and to conduct its validity and reliability study. This study was conducted on 221 participants, 105 of whom were girls and 116 of them were boys. Confirmatory factor analysis was applied to evaluate the construct validity. To determine the reliability of the scale, cronbach's alpha, two-half test reliability and total item correlations were used. Confirmatory factor analysis results showed that, significant chisquare values ( $\chi 2=131.84, S D=77, p=.00010)$ and goodness of fit values are acceptable (RMSEA $=$ $.057, G F I=.92, A G F I=.89, C F I=.93, I F I=.93, N N F I=.92, S R M R=.060)$. The results of the analysis show that the factor structure of the Turkish form of the scale provides good fit values and that the factor structure of the scale is verified in parallel with the original scale. When examined in terms of reliability values, it is seen that the internal-consistency reliability coefficient of the Turkish form of the scale is .78 , two half-test reliability is .76 and the corrected item total correlations are ranked between .26 and .52. The results of the analysis show that the Mindful Attention Awareness Scale Adolescent Turkish Form can be evaluated as a valid and reliable measurement tool.
\end{abstract}

Keywords: Mindful attention awareness, scale adaptation, reliability, validity, confirmatory factor analysis 


\section{Giriş}

Çocuklar ve ergenler için bilinçli-farkındalık temelli müdahalelere olan ilgi gittikçe artmaktadır. Bu durum çocukların ve ergenlerin bilinçli farkındalık düzeylerini değerlendirmek için kullanılabilecek ölçme aracı ihtiyacını ortaya çıkarmaktadır. Alanyazın incelendiğinde bilinçli farkındalığı ölçmek için çok sayıda ölçme aracı geliştirdiği görülmektedir (Baer, Smith, Hopkins, Krietemeyer, ve Toney, 2006; Baer, Smith, ve Allen, 2004; Brown ve Ryan, 2003; Cardaciotto, Herbert, Forman, Moitra, ve Farrow, 2008; Feldman, Hayes, Kumar, Greeson, ve Laurenceau, 2006; Lau vd., 2006; Medvedev, Krägeloh, Narayanan, ve Siegert, 2017; Walach, Buchheld, Buttenmuller, Kleinknecht, ve Schmidt, 2006). Bu ölçme araçları incelendiğinde yetişkinler için geliştirilmiş oldukları göze çarpmaktadır. Yukarıda da değinildiği üzere bilinçli farkındalık temelli müdahaleler sadece yetişkinlere yönelik olarak gerçekleştirilmemekte, çocuklar ve ergenler için de bilinçli farkındalık temelli müdahaleler planlanmakta ve uygulanmaktadır. Bu doğrultuda ergenler için geliştirilmiş olan Bilinçli Farkındalık Ölçeği Ergen Formu'nun (Brown, West, Loverich, ve Biegel; 2011) geçerlik ve güvenirlik çalışmasını gerçekleştirmek hedeflenmiştir.

\section{Bilinçli Farkındalık}

Psikolojik danışmanlık, psikoloji ve psikiyatri alanyazınında bilinçli farkındalık kavramına ilişkin bilimsel ilginin gün geçtikçe arttı̆̆ görülmektedir (Baer ve vd.; 2004; Bao, Xue, ve Kong, 2015; Brown vd., 2011; Wang ve Kong, 2014). Tarihsel açıdan bakıldığında, bilinçli farkındalık kavramı özellikle Budist felsefesinde ele alınan bir kavramdır. Ancak antik yunan felsefesi ve fenomenolojik, varoluşçu, natüralist, transandantalist, insancl yaklaşımlar gibi psikoloji ve felsefe geleneklerinde de bilinçli farkındalığa yakın veya bilinçli farkındalıkla ilişkili kavramların yer aldığı görülmektedir (Brown, Ryan, ve Creswell, 2007).

Bilinçli farkındalık kavramı yüzyıllar öncesine dayanan bir geçmişe sahiptir. Kökeni ise doğu meditasyon uygulamaları ve ritüelleri ile ilişkilendirilmektedir (Green ve Lynn, 2019). Taoizm'de Nei Dan, Hinduizm'de Yoga, Zen Budizm'de Zazen, Yahudilikte Kabala, Güney Asya Budizm'inde Vipassana, Hristiyanlıkta Merkezleme Dua ve Sufizm'de Rabita gibi ritüeller, meditasyon ve benzeri uygulamalar kapsamında ele alınabilir (Aksöz, 2015; 
Bryant, 2015; Keating, 1988; Magid, 2015; Roth, 2015; Thomson, 2000). Müslümanlıktan, Hristiyanlığa, Budizm'den, Hinduizm'e, Avrupa'dan Asya'ya kadar geniş bir yelpazede meditasyon benzeri ritüellerin uygulanmakta olduğu görülmektedir.

Çağdaş ve terapötik amaçla kullanılan bilinçli farkındalık ve meditasyon uygulamaları, doğası gereği genellikle dini uygulama biçimlerinden elde edilen unsurları içermekle birlikte dini yönelimleri referans almaz. Böylelikle terapötik amaçla kullanılan bilinçli farkındalık ve meditasyon uygulamalarında dini bileşenler minimize edilir veya tamamen ortadan kaldırılır (Wisner, 2017). Günümüzdeki bilinçli farkındalık uygulamaları daha çok kanıta dayalı bir biçimde ele alınmaktadır (Kostova, Levin, Lorberg, ve Ziedonis, 2019).

Bilinçli farkındalık ve meditasyon uygulamaları geleneksel psikolojik müdahalelerle birlikte tamamlayıcı müdahaleler olarak kullanılabilir. Ergenlere yönelik de sunulan bu uygulamalar ve programlar, psikolojik danışmanlık, davranışsal sağlık, tıp ve eğitim ortamları gibi çeşitli ortamlarda kullanılabilmektedir. Bu nedenle, ergenlere yönelik gerçekleştirilen müdahalelerde çağdaş, bilimsel bilinçli farkındalık uygulamalarının sunulması önemli görülmektedir (Wisner, 2017). Ayrıca günümüzde hem normal olarak kabul edilen hem de psikiyatrik tanı almış bireyler için bilinçli farkındalık temelli ya da bilinçli farkındalığın entegre edildiği müdahalelerde artış olduğu belirtilmektedir (Baer, 2003; Brown vd., 2011; Brown ve Ryan, 2003; Brown, Ryan, ve Creswell, 2007). Peki bilinçli farkındalık kavramı (mindfullness) neyi işaret etmekte ve anlatmaktadır?

Bilinçli farkındalığı bireyin yaşam akışında ana yani şu andaki zamana dikkat kesilip, eleştiride bulunmadan anlık olarak yaşadığı deneyimi kabul etmesi olarak ifade edebiliriz. Bilinçli farkındalık yargılayıcı olmayan dikkati ifade eden bir kavramdır (Kabat-Zinn, 1994, 2003, 2005). Bilinçli farkındalıkta düşüncelerden daha çok dikkat vurgulanarak gündelik olaylara ve deneyimlere yönelik aralıksız, alıcı dikkat merkeze alınmıştır (Brown ve Ryan, 2003). Bilinçli farkındalık (mindfulness) kavramı dikkat (attention) ve farkındalık (awareness) bileşenlerinden oluşmaktadır (Brown ve Ryan, 2003; Brown, Ryan, ve Creswell, 2007). Sonuç olarak bilinçli farkındalı̆̆ı bireyin şu ana (şu anda yaşananlara) yargisız olarak ve kabullenerek dikkatini odaklaması şeklinde tanımlayabiliriz (Brown ve Ryan, 2003; Kabat-Zinn, 1994). 
Bilinçli farkındalık bireyin yaşam akışında alışkanlıklarından kaynaklanan düşünceler olmadan hareket etmesini sağlayan psikolojik bir yapıdır. Bilinç bu süreçte netlik ve zindelik kazanarak daha esnek ve nesnel psikolojik ve davranışsal tepkiler verir (Brown, Ryan, ve Creswell, 2007). Bilinçli farkındalık düşüncelerin ve duyguların olduğu gibi kabul edilmesini sağlayarak, düşüncelere eşlik eden duygusal sıkıntılarda azalma sağlayabilir. Bilinçli farkındalık temelli müdahalelerin bağışıklık sistemi işlevselliğini arttırdığı, beyin laterizasyonunu değiştirdiği bulunmuştur. Yine düşünme ve başa çıma stilleri ile bağışıklık fonksiyonları ve hastalığa duyarlılık arasında bir bağlantı olduğu da bulunmuştur. (Davidson vd., 2003; Gilbert, ve Irons, 2005; Martin, 1998).

Manevi, psikolojik ve felsefi yaklaşımlar bireyin mutluluğu ve yaşam doyumunda bilinç ve bilince ilişkin kavramlara büyük önem atfetmişlerdir (Baer vd., 2004; Brown ve Ryan, 2003; Lykins ve Baer, 2009; Mayer, 2000). Bilinçli farkındalık, bireyin şu ana uyum sağlamasına yardımcı olur ve bireyin yaşamış olduğu deneyimlere (düşünceler, hisler ve çevre dâhil) ilişkin daha fazla farkındalık geliştirmesini sağlar (Green ve Lynn, 2019). Bilinçli farkındalık ve ilişkili kavramlar, bireyin mutluluğuna ve farkındalığına ilişkin mekanizmalara katkı sağlayabilir. Dolayısı ile bu süreç bilinçli farkındalık temelli müdahalelere olan ilgiyi de arttırmaktadır (Kostova vd., 2019).

Normal ve klinik ergen popülasyonunda bilinçli farkındalık temelli müdahalelere olan ilginin artması (Beauchemin, Hutchins, ve Patterson, 2008; Biegel, Brown, Shapiro, ve Schubert, 2009; Bootzin ve Stevens, 2005; Sams, Handley, ve Alpert-Gillis, 2018; Semple, Lee, Rosa, ve Miller, 2010; Tan, 2015) bu alanda kullanılabilecek psikolojik ölçüm aracı ihtiyacını da arttırmaktadır. Dolayısı ile bu çalışmada Bilinçli Farkındalık Ölçeği Ergen Formu'nu Türkçeye uyarlamak, geçerlik, güvenirlik çalışmasını yapmak ve bilinçli farkındalık temelli müdahaleler için kullanılabilecek ölçme aracı ihtiyacının karşılanmasına katkıda bulunmak amaçlanmıştır.

\section{Yöntem}

\section{Örneklem}

Bu çalışma 221 ergenlik çağındaki birey üzerinden yürütülmüş̧ür. Katılımc1ların 105'i kız, 116'sı erkek; 40'1 11. sınıf öğrencisi, 181'i 12. Sınıf öğrencisi; yaş 
ortalaması 17.1'dir. Katılımclar araştırmaya gönüllü olarak katkı sağlamışlardır. Katılımcıların yaşları 15 ile 18 yaş arasında değişmektedir.

\section{İşlem}

Öncelikle Bilinçli Farkındalık Ölçeği Ergen Formu'nu Türkçeye uyarlamak için ölçeğin orijinal makalesinin (Brown vd., 2011) sorumlu yazarı ile iletişime geçilmiştir. Ölçeğin orijinal makalesinin sorumlu yazarından Türkçe uyarlama çalışmasını gerçekleştirmek üzere izin alınmıştır. Ölçek uyarlama çalışması birçok adımdan oluşan ve oldukça dikkatli bir şekilde gerçekleştirilmesi gereken bir çalışmadır. Ölçek uyarlama çalışmalarında kültürler arası farkl1lıkların dikkate alınması gerekmektedir. Kültürler arası farklılıklara özellikle çeviri aşamasında dikkat edilmelidir. Ölçek uyarlama çalışmalarında ölçeğin anlaşılırlığına ve toplumun sosyo-kültürel bağlamda genel anlayışına dikkat edilmezse ölçme aracının geçerliği ve güvenirliği bu durumdan etkilenebilir. Bu durum ölçme aracının sağlıklı sonuçlar vermemesine neden olabilir (Boztunç Öztürk, Eroğlu, ve Kelecioğlu, 2015; Çapık, Gözüm, ve Aksayan, 2018; Erkuş, 2007; Karakoç ve Dönmez, 2014). Ölçeğin çeviri çalısması tamamlandıktan sonra ölçeğin maddeleri iyi düzeyde İngilizce bilen psikolojik danışma ve rehberlik alanında doktora derecesine sahip 4 uzmana incelettirilmiştir. Ölçeğin İngilizce ve Türkçe formlarını eş zamanlı olarak inceleyen uzmanlardan gelen geri bildirimler doğrultusunda ölçek maddelerine son hali verilmiştir.

Ölçek uyarlama çalışmalarında, ölçeğin geçerliği için yapı geçerliği ve kapsam geçerliği çalışmalarının yapılması önerilmektedir. Kapsam geçerliği uzman görüşü, yapı geçerliği doğrulayıcı faktör analizi ile değerlendirilmektedir. Güvenirlik çalışmalarının ise cronbach's alpha, iki yarı test güvenirliği ve düzeltilmiş madde toplam puan korelasyonları ile gerçekleştirilmesi önerilmektedir (Büyüköztürk, 2012; Çokluk, Şekercioğlu, ve Büyüköztürk, 2010; Spahi, Yurtkoru, ve Çinko, 2008).

Şimşek (2007) teori ile gerçek ayırımını anlayabilmek için açımlayıcı faktör analizi ile belirlenmiş faktör yapılarına doğrulayıcı faktör analizi uygulanabileceğini ifade etmiştir. Yapı geçerliğini belirlemek amacıyla ölçeğin orijinal faktör yapısının doğrulanıp doğrulanmadığını belirlemek amacıyla ölçeğin 
Türkçe formuna doğrulayıcı faktör analizi uygulanmıştır. Ölçeğin güvenirliği cronbach's alpha, iki yarı test güvenirliği ve düzeltilmiş madde toplam puan korelasyonları ile değerlendirilmiştir (Jöreskog ve Sörbom, 1993).

\section{Veri Toplama Araçları}

Bilinçli farkındalık ölçeği ergen formu: Bilinçli Farkındalık Ölçeği Ergen Formu ergenlerin bilinçli farkındalık düzeylerini değerlendirmek üzere geliştirilen öz-bildirime dayalı bir ölçme aracıdır (Brown vd., 2011). Daha önce yetişkinler için geliştirilen form (Brown ve Ryan, 2003) ergenlere uyarlanmıştır (Brown vd., 2011). Çalışmada ergenlere uyarlanan form kullanılmıştır. Yetişkinler için geliştirilen formun kültürümüze uyarlanma çalışmasında iç tutarlılık güvenirlik katsayısı .80 olarak bulunmuştur (Özyeşil, Aslan, Kesici, ve Deniz, 2011). Ölçeğin yetişkin formu 15 madde ve tek boyut, ergen formu ise 14 madde ve tek boyuttan oluşmaktadır (Brown ve Ryan, 2003; Brown vd., 2011).

Üstbiliş ölçeği çocuk ve ergen formu: Üstbiliş Ölçeği Çocuk ve Ergen Formu öz-bildirime dayanan ve 24 maddeden oluşan bir ölçme aracıdır (Bacow, Pincus, Ehrenreich, ve Brody, 2009). Endişeyi ve istem dışı düşünceleri değerlendiren bir ölçektir. Çocuk ve ergenlerin üstbilişsel değerlendirmelerini ölçen ölçme aracının dört alt boyutu bulunmaktadır. Her alt boyut altı maddeden oluşmaktadır. Ölçeğin alt boyutları olumlu üst endişeler, olumsuz üst endişeler, batıl inançlar, ceza ve sorumluluk inançları ve bilişsel izleme olarak adlandırılmıştır. Ölçeğin iç tutarlılık güvenirlik katsayısı .73 olarak bulunmuştur (Irak, 2012).

\section{Bulgular}

\section{Yapı Geçerliği}

Doğrulayıcı faktör analizi: Ölçeğin yapı geçerliğini sınamak amacıyla doğrulayıcı faktör analizi uygulanmıştır. Analiz sonuçları ki-kare değerinin anlamlı $(\chi 2=131.84, \mathrm{SD}=77, \mathrm{p}=.00010)$ ve uyum iyiliği değerlerinin kabul edilebilir $(\mathrm{RMSEA}=.057, \mathrm{GFI}=.92, \mathrm{AGFI}=.89, \mathrm{CFI}=.93$, IFI $=.93$, NNFI $=.92$, $\mathrm{SRMR}=.060$ ) düzeyde olduğunu göstermiştir. Genel kabul gören kriterlere göre modelin iyi uyum verdiği ifade edilebilir. Ölçeğin faktör yapısına ilişkin faktör yükleri Şekil 1.'de sunulmuştur. 


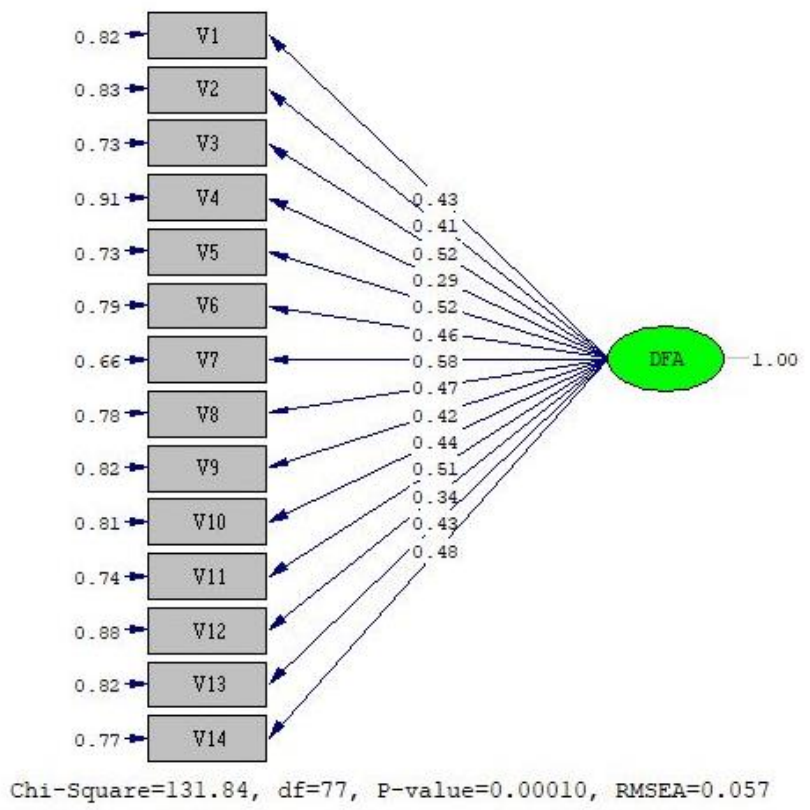

Şekil 1. Bilinçli Farkındalık Ölçeği Ergen Formu'na ilişkin path diyagramı ve faktör yïkleri

\section{Güvenirlik}

Ölçeğin güvenirlik analizleri, cronbach's alpha, iki yarı test güvenirliği ve madde toplam puan korelasyonları ile gerçekleştirilmiştir. Ölçeğin iç tutarlılık güvenirlik katsayısı .78 olarak bulunmuştur. Bilimsel araştırmalarda kullanılacak ölçme araçları için kullanılacak güvenirlik katsayısının .60 ve üzeri olması önerilmektedir (Büyüköztürk, 2012). Ölçeğin iç tutarlılık güvenirlik katsayısının kabul edilebilir bir düzeyde olduğu görülmektedir. Ölçeğin iki yarı test güvenirliği .76 olarak hesaplanmıştır. Ayrıca ölçek için elde edilen düzeltilmiş madde toplam korelasyonları .26 ile .52 arasında sıralanmaktadır. Sonuç olarak ölçek için elde edilen tüm güvenirlik analizleri genel anlamda değerlendirildiğinde, ölçeğin kabul edilebilir düzeyde güvenirliğe sahip olduğu değerlendirilebilir. Ölçeğin cronbach's alpha, iki yarı test güvenirliği ve madde toplam puan korelasyonları ile ilgili değerler Tablo 1.'de sunulmuştur. 
Tablo 1. Ergenler İçin Bilinçli Farkındalık Ölçeği'nin düzeltilmiş madde toplam korelasyon, iç tutarlılık güvenirlik katsayısı, iki yarı test güvenirlik değerleri

\begin{tabular}{llll}
\hline Ölçek maddesi & $\begin{array}{l}\text { Düzeltilmiş } \\
\text { madde-toplam } \\
\text { korelasyonları }\end{array}$ & $\begin{array}{l}\text { İç tutarllık güvenirliği } \\
\text { (Cronbach's alpha) }\end{array}$ & $\begin{array}{l}\text { İki yarn test güvenir- } \\
\text { lik değerleri }\end{array}$ \\
\hline 1. Madde & .37 & - & - \\
2. Madde & .36 & - & - \\
3. Madde & .46 & - & - \\
4. Madde & .26 & - & - \\
5. Madde & .46 & - & - \\
6. Madde & .40 & - & - \\
7. Madde & .52 & - & - \\
8. Madde & .39 & - & - \\
9. Madde & .38 & - & - \\
10. Madde & .41 & - & - \\
11. Madde & .47 & - & - \\
12. Madde & .32 & - & - \\
13. Madde & .37 & - & - \\
14. Madde & .40 & - & .76 \\
Ölçeğin Bütünü & - & .78 & - \\
\hline
\end{tabular}

BFÖ-EF'nun Eş Zamanlı Geçerliliği: Üstbiliş Ölçeği Çocuk Ve Ergen Formu İle Korelasyon Analizleri

Bilinçli Farkındalık Ölçeği Ergen Formu'nun eş zamanlı geçerliliğini incelemek amaciyla ölçekten elde edilen puanlarla Üstbiliş Ölçeği Çocuk ve Ergen Formu alt ölçek ve toplam puanları arasındaki korelasyon, Pearson korelasyon testiyle araştırılmıştır (Tablo 2).

Tablo 2. Bilinçli Farkındalık Ölçeği Ergen Formu'nun Üstbiliş Ölçeği Çocuk ve Ergen Formu ile eş zamanl geçerlilik analizleri

\begin{tabular}{lllllllll}
\hline & & \multicolumn{2}{l}{ Toplam } & \multicolumn{2}{l}{ Kızlar } & \multicolumn{3}{l}{ Erkekler } \\
\hline & Ort. \pm SS & $\mathrm{r}$ & $\mathrm{p}$ & $\mathrm{r}$ & $\mathrm{p}$ & $\mathrm{r}$ & $\mathrm{p}$ \\
\hline $\begin{array}{l}\text { ÜÖ-ÇEF - olumlu üst } \\
\text { endişeler alt ölçeği }\end{array}$ & $14.47 \pm 4.20$ & -.39 & $<0.001$ & -.37 & $<0.001$ & -.44 & $<0.001$ \\
\hline $\begin{array}{l}\text { ÜÖ-ÇEF - olumsuz üst } \\
\text { endişeler alt ölçeği }\end{array}$ & $15.93 \pm 3.4$ & -.55 & $<0.001$ & -.54 & $<0.001$ & -.56 & $<0.001$ \\
\hline $\begin{array}{l}\text { ÜÖ-ÇEF - batıl inançlar, ceza ve } \\
\text { sorumluluk inaçları alt ölçeği }\end{array}$ & $16 \pm 3.71$ & -.37 & $<0.001$ & -.40 & $<0.001$ & -.34 & $<0.001$ \\
\hline $\begin{array}{l}\text { ÜÖ-ÇEF - bilişsel izleme } \\
\text { alt ölçeği }\end{array}$ & $16.89 \pm 3.59$ & -.29 & $<0.001$ & -.37 & $<0.001$ & -.23 & $<0.001$ \\
\hline ÜÖ-ÇEF - toplam puan & $63.28 \pm 12$ & -.52 & $<0.001$ & -.55 & $<0.001$ & -.50 & $<0.001$ \\
\hline
\end{tabular}

İlgili analizler tüm katılımcılar üzerinden hesaplandığı gibi ayrıca kızlar ve erkekler üzerinden de ayrı ayıı hesaplanmıştır. Kızların bilinçli farkındalık 
ölçeği ortalama toplam puanı $50.75 \pm 10.28$, erkeklerin ortalama toplam puanı $52.5 \pm 12.91$ olarak bulunmuştur. Bilinçli Farkındalık Ölçeği Ergen Formu puanı arttıkça, Üstbiliş Ölçeği Çocuk ve Ergen Formu alt ölçek ve toplam ölçek puanlarının hem kızlarda, hem erkeklerde, hem de toplamda istatistiksel olarak anlamlı düzeyde ( $\mathrm{p}<0.001$ ) azaldığı bulunmuştur (Tablo 2).

\section{Tartışma ve Sonuç}

Bu çalışmada Bilinçli Farkındalık Ölçeği Ergen Formu'nun Türkçe'ye uyarlanması, ölçeğin güvenirlik ve geçerlik analizi çalışmalarının yapılması hedeflenmiştir. Böylelikle çocuk ve ergenler için gerçekleştirilecek bilinçli farkındalık temelli müdahaleler için kültürümüzde sınanmış ölçme aracı ihtiyacı karşılanacaktır. Bu doğrultuda ölçeğin doğrulayıcı faktör analizi sonuçları, iç tutarlılık güvenirlik katsayısı, iki yarı test güvenirlik katsayısı, düzeltilmiş madde toplam korelasyonları ve eş zamanlı geçerlilik analizleri incelenmiştir.

Doğrulayıcı faktör analizi sonuçları modelin iyi uyum değerleri ürettiğini göstermektedir. Bu çalışmada doğrulayıcı faktör analizi (DFA) ki-kare değerinin anlamlı $(\chi 2=131.84, \mathrm{SD}=77, p<.001)$, uyum iyiliği değerlerinin kabul edilebilir $(\mathrm{RMSEA}=.057, \mathrm{GFI}=.92$, $\mathrm{AGFI}=.89, \mathrm{CFI}=.93$, $\mathrm{IFI}=.93, \mathrm{NNFI}=.92$, SRMR $=.060$ ) düzeyde olduğu ve bu çalışmanın DFA sonuçlarının orijinal ölçek çalışmasının (Brown vd., 2011) DFA sonuçları ( $\chi 2=141.55, \mathrm{SD}=77, p<$ .001 ve CFI $=.94$, IFI = .94) ile benzerlik taşıdığ görülmektedir.

İç tutarlılık, iki yarı test güvenirlik ve madde toplam korelasyonları ile ölçeğin güvenirliği değerlendirilmeye çalışılmıştır. Güvenirliği değerlendirmek için yapılan analizler, ölçeğin güvenilir bir ölçek olarak değerlendirilebileceğine işaret etmektedir. Bilimsel araştırmalarda kullanılacak ölçme araçları için minimum güvenirlik katsayısının .60 (Büyüköztürk, 2012) veya .70 (Tezbaşaran, 1996) olması gerektiği önerilmektedir. Madde toplam korelasyonları için ise ölçek maddelerinin .30 ve üzeri değer yüklerinin ayırt edici olduğu ifade edilmektedir (Büyüköztürk, 2012). Bu doğrultuda, uyarlama çalışması gerçekleştirilen Türkçe Bilinçli Farkındalık Ölçeği Ergen Formu'nun yeterli düzeyde güvenirlik değerlerine sahip olduğu savunulabilir.

Geçerlik ve güvenirlik analizlerinin sonuçları Bilinçli Farkındalık Ölçeği Ergen Formu'nun bilimsel araştırmalarda kullanılabilecek değer yüklerine sahip olduğunu göstermektedir. Ölçeğin orijinal çalışmasında (Brown vd., 
2011) iç tutarlılık güvenirlik katsayısının iki farklı örneklem grubu üzerinden hesaplandığı görülmektedir. Birinci grup için hesaplanan iç tutarlılık güvenirlik katsayısının .82, ikinci grup için hesaplanan iç tutarlılık güvenirlik katsayısının .84 olduğu görülmektedir. Bu çalışmada hesaplanan iç tutarlılık güvenirlik katsayısının .78 olduğu ve bu değerin orijinal çalışmada yer alan değerlerden çok küçük bir miktarda düşük olduğu görülmektedir. Ancak yine de bu değerin bilimsel araştırmalarda kullanılacak ölçme araçları için önerilen .60 değerinden (Büyüköztürk, 2012) büyük olduğu görülmektedir. Ayrıca eş zamanlı geçerlilik analizi kapsamında bilinçli farkındalık ile psikopatolojilerde rol oynadığı düşünülen üstbilişlerin ilişkisi incelenmiştir. Eş zamanlı geçerlilik analizi sonuçları Bilinçli Farkındalık Ölçeği Ergen Formu puanlarının, Üstbiliş Ölçeği Çocuk ve Ergen Formu alt ölçek ve toplam ölçek puanları ile istatistiksel olarak anlamlı düzeyde $(\mathrm{p}<0.001)$ ilişkili olduğunu göstermiştir (Tablo 2). Bu durum ölçeğin geçerliğine ilişkin kanıt sağlamaktadır (Norman, 2016). BFÖ-EF bu kapsamda geçerli ve güvenilir bir ölçme aracı olarak değerlendirilebilir.

Bu araştırmanın sınırlılıklarına göz attığımızda, öncelikle katılımcıların yaş aralığının 15 ile 18 arasında değiştiği görülmektedir. Dünya Sağlık Örgütü ergenleri 10 ile 19 yaş aralığındaki bireyler olarak tanımlamıştır (WHO, 2006). Bu çalışma farklı yaş aralıklarındaki ergenlerle (örneğin ortaokula devam eden 10 ile 14 yaşındaki ergenler) tekrarlanabilir. Araştırmanın farklı yaş gruplarındaki ergenlerle yeniden tekrarlanması Bilinçli Farkındalık Ölçeği Ergen Formu'nun geçerliğine ve güvenirliğine ilişkin daha kapsamlı bilgiler edinilmesini sağlayabilir.

Ayrıca bu araştırma İstanbul ilinde gerçekleştirilmiştir. Bu çalışma İstanbul dışındaki illerde yaşayan, farklı sosyo-kültürel ortamlarda yetişmiş ve farklı ebeveyn tutumlarıyla yetiştirilmiş ergenlerin katılımıyla tekrarlanabilir. Bu doğrultuda araştırmacılar uyarlaması yapılan ölçme aracının farklı kültürel bağlamlarda verdiği sonuçları değerlendirebilir. Elde edilen sonuçlar ayrıca bölgeler arası kültürel benzerlik ve farklılık örüntülerinin tespit edilmesine de katkı sağlayabilir. 


\title{
EXTENDED ABSTRACT
}

\section{Validity and Reliability Study of Mindful Attention Awareness Scale Adolescent Form}

\author{
Mehmet Emin Turan \\ Agri Ibrahim Cecen University
}

More recently, there has been a growing scientific interest in mindfulness (Baer et al., 2004; Bao, Xue, and Kong, 2015; Brown et al., 2011; Wang and Kong, 2014). From a historical point of view, minfullness is a concept that has been dealt with especially in Buddhist philosophy. However, it is seen that there are concepts close to mindfullness or related to mindfullness in phenomenological, existentialist, naturalist, transcendentalist, humanistic approaches such as psychological and philosophical traditions (Brown, Ryan, and Creswell, 2007). Mindfullness can be expressed as the individual's ability to pay attention to the moment in the flow of life, that is, to the present time, and to accept the instant experience without criticism. Mindfullnes is a concept that expresses non-judgmental attention (Kabat-Zinn, 1994, 2003, 2005). Continuous receptive attention to daily events and experiences is centered, emphasizing more attention than thoughts in mindfullness (Brown and Ryan, 2003). The concept of mindfulness consists of attention and awareness components (Brown and Ryan, 2003; Brown, Ryan, and Creswell, 2007). As a result, mindfullness can be defined as the individual's focus on the present (current events) by accepting and without judgment (Brown and Ryan, 2003; Kabat-Zinn, 1994). Increasing interest in mindfulness-based interventions in normal and clinical adolescent populations (Beauchemin, Hutchins, and Patterson, 2008; Biegel, Brown, Shapiro, and Schubert, 2009; Bootzin and Stevens, 2005; Sams, Handley, and Alpert-Gillis, 2018; Semple, Lee, Rosa, and Miller, 2010; Tan, 2015) also increases the need for psychological measurement tools that can be used in this area. Therefore, in this study, it was purposed to adapt the Mindful Attention Awareness Scale Adolescent Form (MAAS-A) to Turkish, to study its validity and reliability, and to contribute to meeting the need for a measurement tool that can be used for minfullness-based interventions.

This study was conducted by researcher collecting data from 221 adolescents. 105 of the participants are girls and 116 are boys; 40 of them are 11th 
grade students, 181 are 12th grade students; the average age of the participants is 17.1. Participants voluntarily participated to the research. Participants' ages range from 15 to 18 years old. In order to adapt the Mindful Attention Awareness Scale Adolescent Form (MAAS-A) to Turkish, the corresponding author of the original study (Brown et al., 2011) was contacted. Permission was obtained from the corresponding author of the original scale study to perform the Turkish adaptation. Mindful Attention Awareness Scale Adolescent Form (MAAS-A) and Metacognition Questionnaire for Children and Adolescents (MQC-C) were used as data collection tools.

Confirmatory factor analysis was applied to test the construct validity of the scale. The analysis results showed that the chi-square value was significant $(\chi 2=131.84, d f=77, p=.00010)$ and the goodness of fit values were acceptable $(\mathrm{RMSEA}=.057, \mathrm{GFI}=.92, \mathrm{AGFI}=.89, \mathrm{CFI}=.93, \mathrm{IFI}=.93, \mathrm{NNFI}=.92$, SRMR $=.060)$. In this study, the results of the confirmatory factor analysis were found to be similar to the CFA results of the original scale study (Brown et al., 2011). Reliability analyses of the scale were carried out with cronbach's alpha, split-half test reliability and item total score correlations. Internal consistency reliability coefficient of the scale was found to be .78 . The split-half test reliability of the scale was calculated as .76. In addition, the corrected item-total correlations obtained for the scale are ranked between .26 and .52 . In order to examine the concurrent validity of the Mindful Attention Awareness Scale Adolescent Form (MAAS-A), the correlation between the scores obtained from MAAS-A and Metacognition Questionnaire for Children and Adolescents (MQC-C) were investigated with the pearson correlation coefficient. It was found that as the Mindndful Attention Awareness Scale Adolescent Form score increased, the Metacognition Questionnaire for Children and Adolescents (MQC-C) subscale and total scale scores decreased significantly $(p<0.001)$. It can be argued that the Mindndful Attention Awareness Scale Adolescent Turkish Form has acceptable reliability values.

When the limitations of the study are examined, it is seen that the age range of the participants varies between 15 and 18 . This study can be repeated with adolescents of different age ranges (for example, 10 to 14 years old middle school students). Repeating the study with adolescents in different age groups can provide more comprehensive information about the validity and reliability of the Mindndful Attention Awareness Scale Adolescent Form. This research was carried out in the province of Istanbul. This study can be 
repeated with the participation of adolescents living in other cities than Istanbul, raised in different socio-cultural environments and raised with different parental attitudes. Accordingly, researchers can evaluate the results of the adapted measurement tool in different cultural contexts. The results obtained in the present study may also contribute to the determination of cultural similarity and difference patterns between regions.

\section{Kaynakça / References}

Aksöz, T. (2015). İnsan benliğinin arınması. Sakarya Üniversitesi İlahiyat Fakültesi Dergisi, 17(31), 81-81. doi:10.17335/sakaifd.219896

Bacow, T. L., Pincus, D. B., Ehrenreich, J. T. ve Brody, L. R. (2009). The metacognitions questionnaire for children: Development and validation in a clinical sample of children and adolescents with anxiety disorders. Journal of Anxiety Disorders, 23(6), 727-736. doi:10.1016/j.janxdis.2009.02.013

Baer, R. A. (2003). Mindfulness training as a clinical intervention: A conceptual and empirical review. Clinical Psychology: Science and Practice, 10(2), 125143. doi:10.1093/clipsy.bpg015

Baer, R. A., Smith, G. T. ve Allen, K. B. (2004). Assessment of mindfulness by selfreport. Assessment, 11(3), 191-206. doi:10.1177/1073191104268029

Baer, R. A., Smith, G. T., Hopkins, J., Krietemeyer, J. ve Toney, L. (2006). Using self-report assessment methods to explore facets of mindfulness. Assessment, 13(1), 27-45. doi:10.1177/1073191105283504

Bao, X., Xue, S. ve Kong, F. (2015). Dispositional mindfulness and perceived stress: The role of emotional intelligence. Personality and Individual Differences, 78, 48-52. doi:10.1016/j.paid.2015.01.007

Beauchemin, J., Hutchins, T. L. ve Patterson, F. (2008). Mindfulness meditation may lessen anxiety, promote social skills, and improve academic performance among adolescents with learning disabilities. Complementary Health Practice Review, 13(1), 34-45. doi:10.1177/1533210107311624

Biegel, G. M., Brown, K. W., Shapiro, S. E. ve Schubert, C. (2009). Mindfulnessbased stress reduction for adolescent psychiatric outpatients: A randomized clinical trial. Journal of Consulting and Clinical Psychology, 77, 855-866. doi:10.1037/a0016241

Bootzin, R. R. ve Stevens, S. J. (2005). Adolescents, substance abuse, and the treatment of insomnia and daytime sleepiness. Clinical Psychology Review, 25, 629-644. doi:10.1016/j.cpr.2005.04.007 
Boztunç Öztürk, N., Eroğlu, M. G. ve Kelecioğlu, H. (2015). Eğitim alanında yap1lan ölçek uyarlama makalelerinin incelenmesi. Eğitim ve Bilim, 40(178), 123-137. doi:10.15390/eb.2015.4091

Brown, K. W. ve Ryan, R. M. (2003). The benefits of being present: Mindfulness and its role in psychological well-being. Journal of Personality and Social Psychology, 84(4), 822-848. doi:10.1037/0022-3514.84.4.822

Brown, K. W., Ryan, R. M. ve Creswell, J. D. (2007). Mindfulness: Theoretical foundations and evidence for its salutary effects. Psychological Inquiry, 18(4), 211-237. doi:10.1080/10478400701598298

Brown, K. W., West, A. M., Loverich, T. M. ve Biegel, G. M. (2011). Assessing adolescent mindfulness: Validation of an adapted mindful attention awareness scale in adolescent normative and psychiatric populations. Psychological Assessment, 23(4), 1023-1033. doi:10.1037/a0021338

Bryant, E. F. (2015). Hindu Classical Yoga: Patanjali's Yoga Sutras. L. Komjathy (Der.), Contemplative literature: A comparative sourcebook on meditation and contemplative prayer içinde (ss. 457-502). Albany, NY: State University of New York Press.

Büyüköztürk, Ş. (2012). Sosyal bilimler için veri analizi el kitabı. Ankara: Pegem.

Cardaciotto, L., Herbert, J. D., Forman, E. M., Moitra, E. ve Farrow, V. (2008). The assessment of present-moment awareness and acceptance. Assessment, 15(2), 204-223. doi:10.1177/1073191107311467

Çapık, C., Gözüm, S. ve Aksayan, S. (2018). Kültürlerarası ölçek uyarlama aşamaları, dil ve kültür uyarlaması: Güncellenmiş rehber. Florence Nightingale Hemşirelik Dergisi, 26(3), 199-210. doi:10.26650/fnjn397481

Çokluk, Ö., Şekercioğlu, G. ve Büyüköztürk, Ş. (2010). Sosyal bilimler için çok değişkenli istatistik SPSS ve LISREL uygulamaları. Ankara: Pegem.

Davidson, R. J., Kabat-Zinn, J., Schumacher, J., Rosenkranz, M., Muller, D., Santorelli, S. F., ... Sheridan, J. F. (2003). Alterations in brain and immune function produced by mindfulness meditation. Psychosomatic Medicine, 65(4), 564-570. doi:10.1097/01.psy.0000077505.67574.e3

Erkuş, A. (2007). Ölçek geliştirme ve uyarlama çalışmalarında karşılaşılan sorunlar. Türk Psikoloji Bülteni, 13 (40), 17-25. Erişim adresi: https://www.psikolog.org.tr/tr/yayinlar/dergiler/1031828/tpb134004.pdf. 
Feldman, G., Hayes, A., Kumar, S., Greeson, J. ve Laurenceau, J.-P. (2006). Mindfulness and emotion regulation: The development and initial validation of the cognitive and affective mindfulness scale-revised (CAMS-R). Journal of Psychopathology and Behavioral Assessment, 29(3), 177-190. doi:10.1007/s10862-006-9035-8

Gilbert, P. ve Irons, C. (2005). Focused therapies and compassionate mind training for shame and self-attacking. P. Gilbert (Der.), Compassion: Conceptualisations, research and use in psychotherapy içinde (ss. 263-325). New York, NY, US: Routledge.

Green, J. P. ve Lynn, S. J. (2019). Cognitive-behavioral therapy, mindfulness, and hypnosis for smoking cessation. Hoboken, NJ; Wiley Blackwell.

Irak, M. (2012). Standardization of Turkish form of metacognition questionnaire for children: The relationships with anxiety and obsessive-compulsive symptoms. Turkish Journal of Psychiatry, 23, 46-52. doi:10.5080/u6604

Jöreskog, K. G. ve Sörbom, D. (1993). LISREL 8: Structural equation modeling with the SIMPLIS command language. Chicago: Scientific Software International.

Kabat-Zinn, J. (1994). Wherever you go, you are there. Mindfulness meditation in everyday life. New York: Hyperion.

Kabat-Zinn, J. (2003). Mindfulness-based interventions in context: Past, present, and future. Clinical Psychology: Science and Practice, 10(2), 144-156. doi:10.1093/clipsy.bpg016

Kabat-Zinn, J. (2005). Coming to our senses: Healing ourselves and the world through mindfulness. New York: Hyperion.

Karakoç, F. Y. ve Dönmez, L. (2014). Ölçek geliştirme çalışmalarında temel ilkeler. Tip Ĕ̆itimi Dünyası, 13(40), 39-49. doi: 10.25282/ted.228738

Keating, T. (1988). Centering prayer. Chicago, IL: Liturgical Press.

Kostova, Z., Levin, L., Lorberg, B. ve Ziedonis, D. (2019). Mindfulness-based interventions for adolescents with mental health conditions: A systematic review of the research literature. Journal of Child and Family Studies, 28(10), 2633-2649. doi:10.1007/s10826-019-01477-7

Lau, M. A., Bishop, S. R., Segal, Z. V., Buis, T., Anderson, N. D., Carlson, L., ... Devins, G. (2006). The toronto mindfulness scale: Development and validation. Journal of Clinical Psychology, 62(12), 1445-1467. doi:10.1002/jclp.20326 
Lykins, E. L. B. ve Baer, R. A. (2009). Psychological functioning in a sample of long-term practitioners of mindfulness meditation. Journal of Cognitive Psychotherapy, 23(3), 226-241. doi:10.1891/0889-8391.23.3.226

Magid, S. (2015). Jewish kabbalah: Hayyim vital's shaarei kedusha. L. Komjathy (Der.), Contemplative literature: A comparative sourcebook on meditationand contemplative prayer içinde (s. 197-264). Albany, NY: State University of New York Press.

Martin, P. (1998). The sickening mind: Brain, behaviour, immunity and disease. London: Flamingo.

Mayer, J. D. (2000). Spiritual intelligence or spiritual consciousness? International Journal for the Psychology of Religion, 10(1), 47-56. doi:10.1207/s15327582ijpr1001_5

Medvedev, O. N., Krägeloh, C. U., Narayanan, A. ve Siegert, R. J. (2017). Measuring mindfulness: Applying generalizability theory to distinguish between state and trait. Mindfulness, 8(4), 1036-1046. doi:10.1007/s12671017-0679-0

Norman, E. (2016). Metacognition and mindfulness: the role of fringe consciousness. Mindfulness, 8(1), 95-100. doi:10.1007/s12671-016-0494-z

Özyeşil, Z., Aslan, C., Kesici, Ş. ve Deniz, M. E. (2011). Bilinçli Farkındalık Ölçeği'ni Türkçeye uyarlama çalışması. Eğitim ve Bilim, 36(160), 224-235. http://egitimvebilim.ted.org.tr/index.php/EB/article/view/697 adresinden erişilmiştir.

Roth, H. D. (2015). Daoist apophatic meditation: Selections from the classical daoist textual corpus. L. Komjathy (Der.), Contemplative literature: A comparative sourcebook on meditation and contemplative prayer içinde (ss. 89-144). Albany, NY: State University of New York Press.

Sams, D. P., Handley, E. D. ve Alpert-Gillis, L. J. (2018). Mindfulness-based group therapy: Impact on psychiatrically hospitalized adolescents. Clinical Child Psychology and Psychiatry, 23(4), 582-591. doi:10.1177/1359104518775144

Semple, R. J., Lee, J., Rosa, D. ve Miller, L. F. (2010). A randomized trial of mindfulness-based cognitive therapy for children: Promoting mindful attention to enhance social-emotional resiliency in children. Journal of Child and Family Studies, 19, 218 -229. doi:10.1007/s10826-009-9301-y

Spahi, B. Yurtkoru, E. S. ve Çinko, M. (2008). Sosyal bilimlerde SPSS'le veri analizi. İstanbul: Beta.

Şimşek, Ö. F. (2007). Yapısal eşitlik modellemesine giriş temel ilkeler ve LISREL uygulamaları. Ankara: Ekinoks. 
Tan, L. B. (2015). A critical review of adolescent mindfulness-based programmes. Clinical Child Psychology and Psychiatry, w21(2), 193-207. doi:10.1177/1359104515577486

Tezbaşaran, A. (1996). Likert tipi ölçek geliştirme klavuzu. Ankara: Psikologlar Derneği Yayınları.

Thomson, R. F. (2000). Zazen and psychotherapeutic presence. American Journal of Psychotherapy, 54(4), 531-548. doi:10.1176/appi.psychotherapy.2000.54.4.531

Walach, H., Buchheld, N., Buttenmüller, V., Kleinknecht, N. ve Schmidt, S. (2006). Measuring mindfulness-the Freiburg Mindfulness Inventory (FMI). Personality and Individual Differences, 40(8), 1543-1555. doi:10.1016/j.paid.2005.11.025

Wang, Y. ve Kong, F. (2014). The role of emotional intelligence in the impact of mindfulness on life satisfaction and mental distress. Social Indicators Research, 116(3), 843-852. doi:10.1007/s11205-013-0327-6

Wisner, B. L. (2017). Mindfulness and meditation for adolescents. Palgrave Macmillan: New York. doi:10.1057/978-1-349-95207-6

World Health Organization. (2006). Orientation programme on adolescent health for health-care providers. Handout New Modules. 11 Kasım 2020 tarihinde, https://apps.who.int/iris/bitstream/handle/10665/42868/9241591269_Ha ndout_eng.pdf?sequence $=2$ adresinden erişildi.

\section{Kaynakça Bilgisi / Citation Information}

Turan, M. E. (2020). Bilinçli farkındalık ölçeği ergen formu'nun geçerlik ve güvenirlik çalışması. OPUS-Uluslararası Toplum Araştırmaları Dergisi, 16(Eğitim ve Toplum Özel Sayıs1), 5608-5625. DOI: 10.26466/opus. 683364 